\title{
Palygorskite Loaded with Nanoscale Zero-Valent Iron as an Effective Stabilizer for Remediation of Soil Contaminated by $\mathrm{Cd}$ and $\mathrm{Pb}$
}

\author{
Xuan Mi ${ }^{1,4}$, Hanru Ren${ }^{1}$, Yunlong Tong ${ }^{1}$, Jun Ren ${ }^{1,2,3 *}$, Ling Tao ${ }^{1,2,3}$ \\ ${ }^{1}$ School of Environmental and Municipal Engineering, Lanzhou Jiaotong University, Lanzhou 730070, P. R. China \\ ${ }^{2}$ Key Laboratory of Yellow River Water Environment in Gansu Province, Lanzhou 730070, China \\ ${ }^{3}$ Gansu Hanxing Environmental Protection Co., Ltd., Lanzhou 730070, China \\ ${ }^{4}$ College of Geography and Environmental Engineering, Lanzhou City University, Lanzhou 730070, P. R. China
}

Received: 10 February 2021

Accepted: 15 May 2021

\begin{abstract}
Nowadays, the remediation of agricultural soils polluted by $\mathrm{Cd}$ and $\mathrm{Pb}$ is urgently required. In this study, we used the palygorskite (PAL) as a carrier for nanoscale zero-valent iron (nZVI) to synthesize a new type of stabilizer (PAL-nZVI). After 45 days of incubation, the soil $\mathrm{pH}$ increased by $1.80 \mathrm{pH}$ units. The batch experiments exhibited that the bioavailability and leaching toxicity decreased significantly $(\mathrm{P}<0.05)$ with the addition of PAL-nZVI. The data concluded that the 30 days was a critical period for $\mathrm{Cd}$ and $\mathrm{Pb}$ stabilization and the optimum dosage of PAL-nZVI was 6\%. Moreover, the application of PAL-nZVI could transform the speciation of $\mathrm{Cd}$ and $\mathrm{Pb}$ from labile fraction to stable fraction (the maximum residual percentage of $\mathrm{Cd}$ and $\mathrm{Pb}$ increased by $27.34 \%$ and $36.57 \%$, respectively) after 30 days of incubation. The pot experiments indicated that the application of PAL-nZVI could enhance the growth of corn (Zea mays L.), reduce the accumulation of heavy metals from the soil and decrease the phytotoxicity of $\mathrm{Cd}$ and $\mathrm{Pb}$ in the soil. These results suggested that the PAL-nZVI, which is high-efficiency and low-cost, can be a feasible stabilizer for the soils contaminated by $\mathrm{Cd}$ and $\mathrm{Pb}$.
\end{abstract}

Keywords: Palygorskite, nanoscale zero-valent iron, stabilization, heavy metals, soil

\section{Introduction}

Environmental problems in agricultural soils with increasing heavy metal pollutants have become a worldwide issue over the last few decades, which is crucial for the environmental safety and human health [1-3]. Heavy metal accumulation in the soil is a

*e-mail: renjun@mail.lzjtu.cn complex and dynamic process which affected by many factors, such as mining, smelting, traffic emissions and other anthropogenic activities [4]. Cadmium (Cd) and lead $(\mathrm{Pb})$ are regarded as the primary poisonous elements which are widespread in soil due to their higher toxicity and bioaccumulation than other heavy metals [5-7]. According to the first national report by the Chinese government, $19.4 \%$ of Chinese agricultural soils had been contaminated by heavy metals, and the over-standard rate of $\mathrm{Cd}$ and $\mathrm{Pb}$ attained $7 \%$ and $1.5 \%$, respectively. Because of the high bioaccumulation of 
heavy metal, they would hardly be degraded in the ecosystem and permanently exist when they enter the soil and groundwater. This non-biodegradability causes another hot issue need to be vigilant in China-food safety. When the heavy metal accumulated in human and animals through the soil-crop food chain, it could cause severe impairment for immune, nervous and endocrine systems and destroy the function of the liver, fertility and kidneys [8]. Therefore, it is imperative to develop a practicable and effective method to reduce the toxicity of heavy metals and remediate the $\mathrm{Cd}$ and $\mathrm{Pb}$ contaminated soil.

Currently, there are a large number of techniques have been employed to remediate the soil contaminated by heavy metals, such as electrokinetic remediation, coagulation, phytoremediation, in-situ stabilization and leaching technology [9]. Among these techniques, in-situ stabilization, which is not limited by the cost and application scale, has been getting great attention around the world. In order to choose a cheap, ecofriendly and readily available material as the in-situ adsorbent, many materials have been tested, containing zeolite [10-11], lime [12], biochar [13], sepiolite [14] and hydroxyapatite [15]. Nanoscale zero-valent iron (nZVI), relies on its particular core-shell construction, superior reactivity and high adsorption capacity, which has become a potential remediation material [16-17]. It has attracted much attention to improving the quality of heavy metal polluted soil [18-19]. Unfortunately, there are still obvious technical challenges that hinder its application in the field. Because of the magnetic, van der Waals and its nano-size effects, it could be oxidized and aggregated immediately, which reduces the reaction activity sites and then decrease the sorption capacity [20-21]. To address this deficiency, the incorporation of another supported material is one of the feasible strategies to overcome these troubles of nZVI [22-23].

Palygorskite, a kind of natural inorganic mineral material, possesses a large number of active sites on the internal and external surface due to its mesoporous structures, which could be used as an effective amendment to remediate the combined contaminated soil [24-28]. Hence, the palygorskite should be a suitable supported material for nZVI to enhance its active sites and improve its sorption capacity. On the one hand, the palygorskite can serve as a considerable carrier because of its large specific surface and high thermal stability. When the nanoscale zero-valent iron coated with palygorskite, it could disperse uniformly on the surface of palygorskite as the nano-particles to prevent its aggregation. On the other hand, because a large number of useful functional groups $(-\mathrm{OH}, \equiv \mathrm{Si}-\mathrm{OH}$, etc.), which exist on the surface of palygorskite, could stabilize the heavy metals by complexation, cation exchange or electrostatic action [29-30]. The possible stabilization mechanism of $\mathrm{Cd}$ and $\mathrm{Pb}$ by PAL-nZVI was shown in Fig. 1. What's more, nanoscale zero-valent iron is a relatively expensive material, the cost of remediation can be decreased significantly when the palygorskite load with nanoscale zero-valent iron [31]. However, very litter reports use the palygorskite modified with nZVI to remediate the heavy metals contaminated soil. Most of them concentrated on applying the amendment in the aqueous solutions [31-33], and the stabilization mechanisms of PAL-nZVI and ecological risks in the soil is unclear.

The main objectives of this study were to (1) synthesize and characterize the PAL-nZVI; (2) elucidate the change of amended-soil property; (3) investigate the optimum dosage and reaction time for immobilization efficiency of $\mathrm{Cd}$ and $\mathrm{Pb}$ in the soil; (4) explore the change of $\mathrm{Cd}$ and $\mathrm{Pb}$ speciation in the soil after amended by PAL-nZVI and explain the stabilization mechanisms; (5) confirm whether PAL-nZVI could decrease the phytotoxicity of $\mathrm{Cd}$ and $\mathrm{Pb}$ in polluted soil and promote the growth of the plant.

\section{Material and Methods}

\section{Soil Description}

The metal-contaminated soil samples with $19.15 \pm 0.58 \mathrm{mg} / \mathrm{kg} \mathrm{Cd}$ and $94.21 \pm 1.46 \mathrm{mg} / \mathrm{kg} \mathrm{Pb}$ was collected from the surface layer $(0-20 \mathrm{~cm})$ in Baiyin, Gansu, Northwest China (36 29'39"N, 104 $\left.16^{\circ} 5^{\prime \prime} \mathrm{E}\right)$. The soil was contaminated with cadmium and lead severely because of the historical lead-zinc smelting and mining. It was a low-permeability clay layer that tended to accumulate heavy metals in the discharged industrial effluents [34]. Now the land is still used as cropland and the plants, such as corns, celeries are planted in the soil. The soil samples were airdried, ground and sieved with a $2-\mathrm{mm}$ mesh, then the samples were stored in the dryer for future use. The concentration of $\mathrm{Cd}$ and $\mathrm{Pb}$ in soil were determined by atomic absorption spectrometry (AAS, Persee TAS-990) after digesting with $\mathrm{HNO}_{3}-\mathrm{HCl}-\mathrm{HClO}_{4}$ $(v: v: v=1: 3: 1)$. The other essential physicochemical properties of soil were $\mathrm{pH}$ of $4.82 \pm 0.02$, cation exchange capacity of $12.8 \pm 1.5 \mathrm{cmol} / \mathrm{kg}$; EC of $2.11 \pm 0.04 \mathrm{dS} / \mathrm{m}$; organic matter of $2.94 \pm 0.3 \%$.

\section{Preparation and Characterization of Materials}

Palygorskite was purchased from Gansu Hanxin Environmental Protection Co. Ltd. and collected from Banqiao town, Linze county of Gansu province, China. The ingredients were palygorskite of $36 \%$, quartz of $28 \%$, feldspar of $11 \%$, dolomite of $15 \%$, chlorite of $7 \%$ and muscovite of $1-2 \%$, respectively. Before use, the palygorskite was acid-activated by the $4 \mathrm{M} \mathrm{HCl}$ for $24 \mathrm{~h}$ at room temperature. Centrifugation to separate the solid from solution and washed the PAL until neutral $(\mathrm{pH}=7 \pm 0.5)$ with deionized water. The acid-activated PAL was dried at $105^{\circ} \mathrm{C}$, and then calcinated in a muffle furnace for $2 \mathrm{~h}$ at $400^{\circ} \mathrm{C}$. 


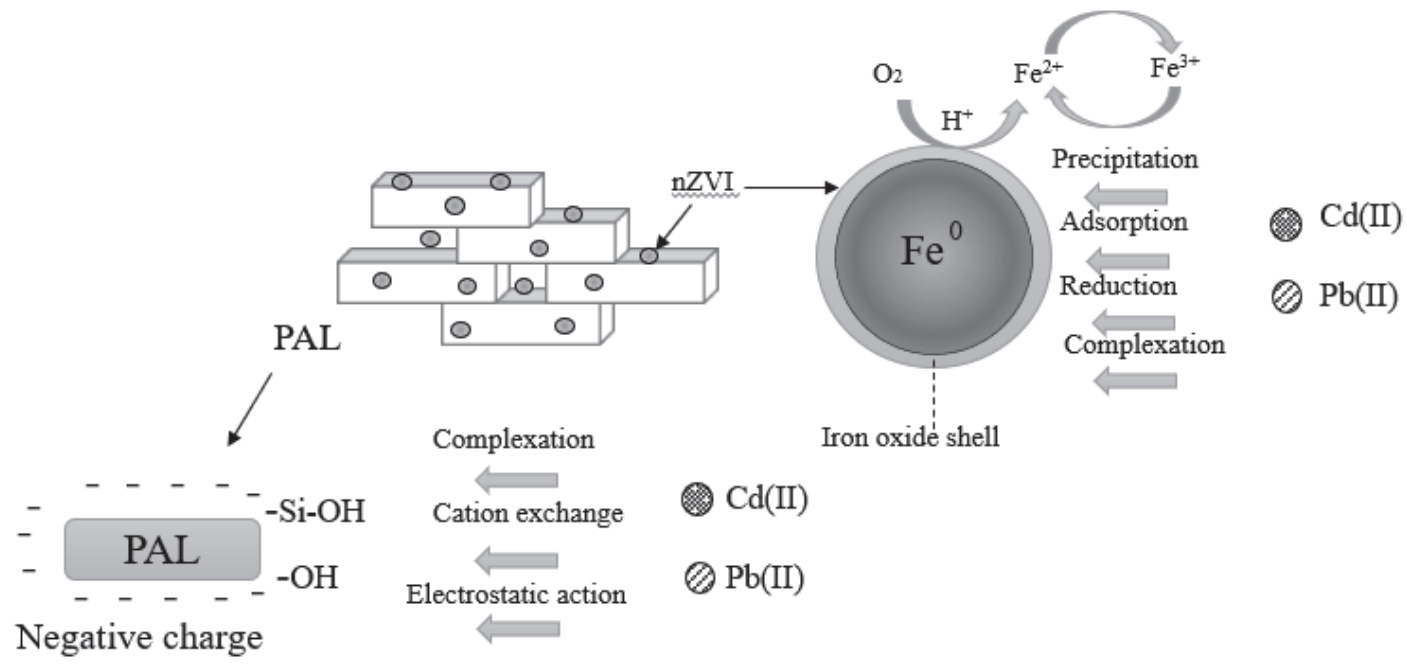

Fig. 1. The possible stabilization mechanism of $\mathrm{Cd}$ and $\mathrm{Pb}$ by PAL-nZVI [29-30].

Then the sample was sieved through a $0.149 \mathrm{~mm}$ mesh to use.

The PAL-nZVI with a palygorskite/iron mass ratio of 2:1 was synthesized by the following method: $20 \mathrm{~g}$ PAL was added to $500 \mathrm{~mL} 0.18 \mathrm{~mol} / \mathrm{L} \mathrm{FeSO}_{4} \cdot 7 \mathrm{H}_{2} \mathrm{O}$ $(99.5 \%)$ and stirred $12 \mathrm{~h}$ at $25 \pm 2^{\circ} \mathrm{C}$ using an electrical stirrer. Secondly, the mixture was transferred to a three-necked flask, $500 \mathrm{~mL}$ of freshly prepared $\mathrm{KHB}_{4}$ $(0.8 \mathrm{~mol} / \mathrm{L})$ solution was added dropwise into the mixture while constantly stirring for another $1 \mathrm{~h}$, and the entire process was under the protection of high purity nitrogen. Then, separating the black products from the liquid phase and washed solids with deoxygenated ultrapure water and deoxygenated absolute ethanol for several times to remove the residual chloride and borohydride. Finally, put the products in a vacuum drying oven at $50^{\circ} \mathrm{C}$ for $4 \mathrm{~h}$ and stored in a vacuum dryer [22].

The surface morphology and particle size of the PAL, nZVI and PAL-nZVI samples was observed with scanning electron microscopy (SEM, Zeiss Supra $55 \mathrm{VP}$, Germany). The function groups on the surface of materials were obtained by fourier transform infrared spectroscopy (FT-IR, VERTEX 70, Germany) over $4000-400 \mathrm{~cm}^{-1}, 32$ scans were taken.

\section{Remediation of $\mathrm{Cd}$ and $\mathrm{Pb}$-Contaminated Soil}

The remediation experiments were performed with $500 \mathrm{~g}$ contaminated soil in a plastic pot with a constant moisture content of $70 \%$ at room temperature $\left(25 \pm 2^{\circ} \mathrm{C}\right)$. In order to assess the dosage of PAL-nZVI on $\mathrm{Cd}$ and $\mathrm{Pb}$ stabilization efficiency, $5 \mathrm{~g} / \mathrm{kg}, 20 \mathrm{~g} / \mathrm{kg}, 40 \mathrm{~g} / \mathrm{kg}$, $60 \mathrm{~g} / \mathrm{kg}$ and $80 \mathrm{~g} / \mathrm{kg}$ of PAL-nZVI $(0.5 \%, 2 \%, 4 \%, 6 \%$, $8 \% \mathrm{w} / \mathrm{w})$ were applied in the soil samples. The mixtures were incubated for $15,30,45$ days to assess the reaction time on $\mathrm{Cd}$ and $\mathrm{Pb}$ stabilization efficiency. After 15, 30 and 45 days of incubation, $100 \mathrm{~g}$ subsamples from each pot were carried out to analyze the physicochemical properties and bioinformatics of soil. Meanwhile, the contaminated soil sample without adding PAL-nZVI was used as the control (CK).

\section{$\mathrm{CaCl}_{2}$ Extraction}

The effect of PAL-nZVI at different dosage and treatment time on the bioavailability of heavy metals was assessed by $0.01 \mathrm{M} \mathrm{CaCl}_{2}$. Briefly, $1 \mathrm{~g}$ dried soil samples were reacted with $25 \mathrm{~mL}$ of $0.01 \mathrm{M} \mathrm{CaCl}_{2}$ solution at $25^{\circ} \mathrm{C}$ and shook for $120 \mathrm{~min}$. After extraction, the samples were centrifuged at $3000 \mathrm{r} / \mathrm{min}$ for $2 \mathrm{~min}$ and the supernatant filtered the $0.45 \mu \mathrm{m}$ membrane before to measure the $\mathrm{Cd}$ and $\mathrm{Pb}$ concentration by AAS.

\section{Toxicity Characteristic Leaching Procedure (TCLP) Text}

In order to evaluate the potential mobility and availability of $\mathrm{Cd}$ and $\mathrm{Pb}$ in the contaminated soil, the toxicity characteristics leaching procedure (TCLP), which was based on the US EPA Method 1311 (1992) was adopted. Briefly, measured accurately $5.7 \mathrm{~mL}$ glacial acetic acid in a $500 \mathrm{~mL}$ volumetric flask and added the deionized water to scale-line as a leaching solution and used $1 \mathrm{~mol} / \mathrm{L}^{\mathrm{HNO}_{3}}$ or $1 \mathrm{~mol} / \mathrm{L} \mathrm{NaOH}$ dropwise to regulate the $\mathrm{pH}$ as $2.88 \pm 0.01$. Weighed $1.0 \mathrm{~g}$ dried soil sample and extracted using $20 \mathrm{~mL}$ leaching solution at $25^{\circ} \mathrm{C}$ in a $50 \mathrm{~mL}$ centrifuge tube and was shaken at $30 \mathrm{r} / \mathrm{min}$ for $18 \mathrm{~h}$. Then centrifuged the slurry at $3000 \mathrm{r} / \mathrm{min}$ for $2 \mathrm{~min}$ after extraction and filtered the supernatant to the $0.45 \mu \mathrm{m}$ membrane. Finally, using the AAS to determine the concentration of $\mathrm{Cd}$ and $\mathrm{Pb}$ in the supernatant.

\section{BCR Sequential Extraction}

The toxicity and bioavailability of heavy metals are closer dependent upon their speciation than their total 
contents in soil. The European Community Bureau of Reference (BCR) four-step sequential extraction was adopted to determine the PAL-nZVI at different dosage and treatment time on the change of the $\mathrm{Cd}$ and $\mathrm{Pb}$ speciation in soil. It partitioned the heavy metals into four fractions: acid exchangeable fraction, reducible fraction, oxidizable fraction and residual fraction. The recovery rate of $\mathrm{Cd}$ and $\mathrm{Pb}$ in this test ranged from $94.95 \%$ to $110.35 \%$ and $92.55 \%$ to $101.74 \%$, respectively. After each extraction, the acidified solutions were filtered through $0.45 \mu \mathrm{m}$ membrane to measure the content of $\mathrm{Cd}$ and $\mathrm{Pb}$ in each fraction by AAS.

The potential ecological risk index $\left(\mathrm{E}_{\mathrm{r}}\right)$ was used to evaluate the ecological risk from heavy metals in the soil and the index can be calculated as the following formulas according to [23]:

$$
\mathrm{E}_{\mathrm{r}}^{\mathrm{i}}=\mathrm{T}_{\mathrm{r}}^{\mathrm{i}} \times \frac{\mathrm{C}_{\mathrm{d}}^{\mathrm{i}}}{\mathrm{C}_{\mathrm{r}}^{\mathrm{i}}}
$$

...where $\mathrm{T}_{r}{ }^{\mathrm{i}}$ is the toxic-response factor for heavy metal and the $\mathrm{Cd}=30, \mathrm{~Pb}=5, \mathrm{C}_{\mathrm{d}}{ }^{\mathrm{i}}$ is the present concentration of heavy metals in soil, $\mathrm{C}_{\mathrm{r}}{ }^{\mathrm{i}}$ is the national criteria (China) for heavy metal in soil and the $\mathrm{Cd}=0.45 \mathrm{mg} / \mathrm{kg}$, $\mathrm{Pb}=250 \mathrm{mg} / \mathrm{kg}$. The evaluation standard for $\mathrm{E}_{\mathrm{r}}{ }^{\mathrm{i}}$ index is shown in Table 1.

\section{Pot Experience}

The PAL-nZVI was applied in the contaminated soil at the rate of $0,0.5,2,4,6,8 \%(w / w)$. In each pot, $1.5 \mathrm{~kg}$ soil and PAL-nZVI mixture was added with three replications of each treatment. Incubated per treatment for 30 days with a constant moisture content of $70 \%$ at room temperature $\left(25 \pm 2^{\circ} \mathrm{C}\right)$, then planted 10 corn seeds in each pot. After 50 days, the shoot and root part of the corn was harvested using stainless steel scissors, respectively. Using the deionized water to rinse the corn's shoot and root part, measured their length by ruler and weighted the fresh weight of harvested plant material. The plant samples were put in the drying oven at $75^{\circ} \mathrm{C}$ for $48 \mathrm{~h}$ to let them dry thoroughly and obtained the dry-weight of samples. Then the dried plant samples were ground and sieved through a $0.149 \mathrm{~mm}$ mesh to measure the uptake of $\mathrm{Cd}$ and $\mathrm{Pb}$ in the corn's shoot and root part, respectively. Briefly, adding the $15 \mathrm{~mL} \mathrm{HNO}_{3}$ and $1 \mathrm{~mL} \mathrm{HClO}_{4}$ to $0.2000 \mathrm{~g}$ (dry weight) plant sample in the teflon crucible to make the wet digestion. Then filtered the digested solution to the $0.45 \mu \mathrm{m}$ membrane and diluted to $50 \mathrm{~mL}$ ultrapure water in a volumetric flask and determine the concentration of total $\mathrm{Cd}$ and $\mathrm{Pb}$ by $\mathrm{AAS}$.
In order to further explore the efficiency of PAL-nZVI remediation on the translocation capability of $\mathrm{Cd}$ and $\mathrm{Pb}$ for corn, the bioconcentration factors (BCF) and translocation factor (TF) were calculated as follows [35-36]:

$$
\begin{gathered}
\text { Bioconcentration factors }(\mathrm{BCF})= \\
\frac{\text { heavy meatals in the shoot or root parts of plants }(\mathrm{mg} / \mathrm{kg})}{\text { heavy meatals in the soil }(\mathrm{mg} / \mathrm{kg})} \\
\text { Transfer factor }(\mathrm{TF})= \\
\frac{\text { heavy meatals in the aboveground parts of plants }(\mathrm{mg} / \mathrm{kg})}{\text { heavy meatals in the root of plants }(\mathrm{mg} / \mathrm{kg})}
\end{gathered}
$$

\section{Statistical Analysis}

The data set were subjected using the one-way ANOVA to analyze their variance, which processed using the SPSS 18.0 (IBM, USA) for Windows. Using the least significant difference (LSD) method to determine the significant difference among treatments and assign the same letter on the top of the histogram $(\mathrm{P}<0.05)$.

The immobilization efficiency (IE) of $\mathrm{Cd}$ and $\mathrm{Pb}$ were calculated as follows [20]:

$$
\operatorname{IE}(\%)=\left(1-\mathrm{C}_{\mathrm{PAL}-\mathrm{nZVI}} / \mathrm{C}_{\mathrm{CK}}\right) \times 100 \%
$$

...where $\mathrm{C}_{\text {PAL-nZVI }}$ is the $\mathrm{Cd} / \mathrm{Pb}$ concentration under various extraction methods when the contaminated soil was amended by PAL-nZVI; $\mathrm{C}_{\mathrm{CK}}$ is the $\mathrm{Cd} / \mathrm{Pb}$ concentration under various extraction methods in control tests without any amendment.

\section{Results and Discussion}

\section{Characterization of the Material}

The SEM images of PAL, nZVI, PAL-nZVI were shown in Fig. 2(a-c) which could display the surface morphology of them. We could see clearly from Fig. 2b), because of the magnetism and Vander Waals forces, the bare nZVI had an apparent aggregation and presented the chain-like structures, which was consistent with $\mathrm{Li}$ et al. found [37]. After loading the nZVI with palygorskite, the surface of PAL turned rougher obviously shown from Fig. 2a) and c), which indicated that the metal(loid) ions had been captured on the surface or pores of palygorskite successfully. As shown in Fig. 2c), the spherical nanoparticles (approximately $40-60 \mathrm{~nm}$ ) distributed homogeneously on the surface of multilayered palygorskite.

Table 1. Evaluation standard for $\mathrm{E}_{\mathrm{r}}^{\mathrm{i}}$ index [18].

\begin{tabular}{|c|c|c|c|c|}
\hline$<40$ & $40-80$ & $80-160$ & $160-320$ & $>320$ \\
\hline Low risk & Moderate risk & Considerable risk & High risk & Very high risk \\
\hline
\end{tabular}



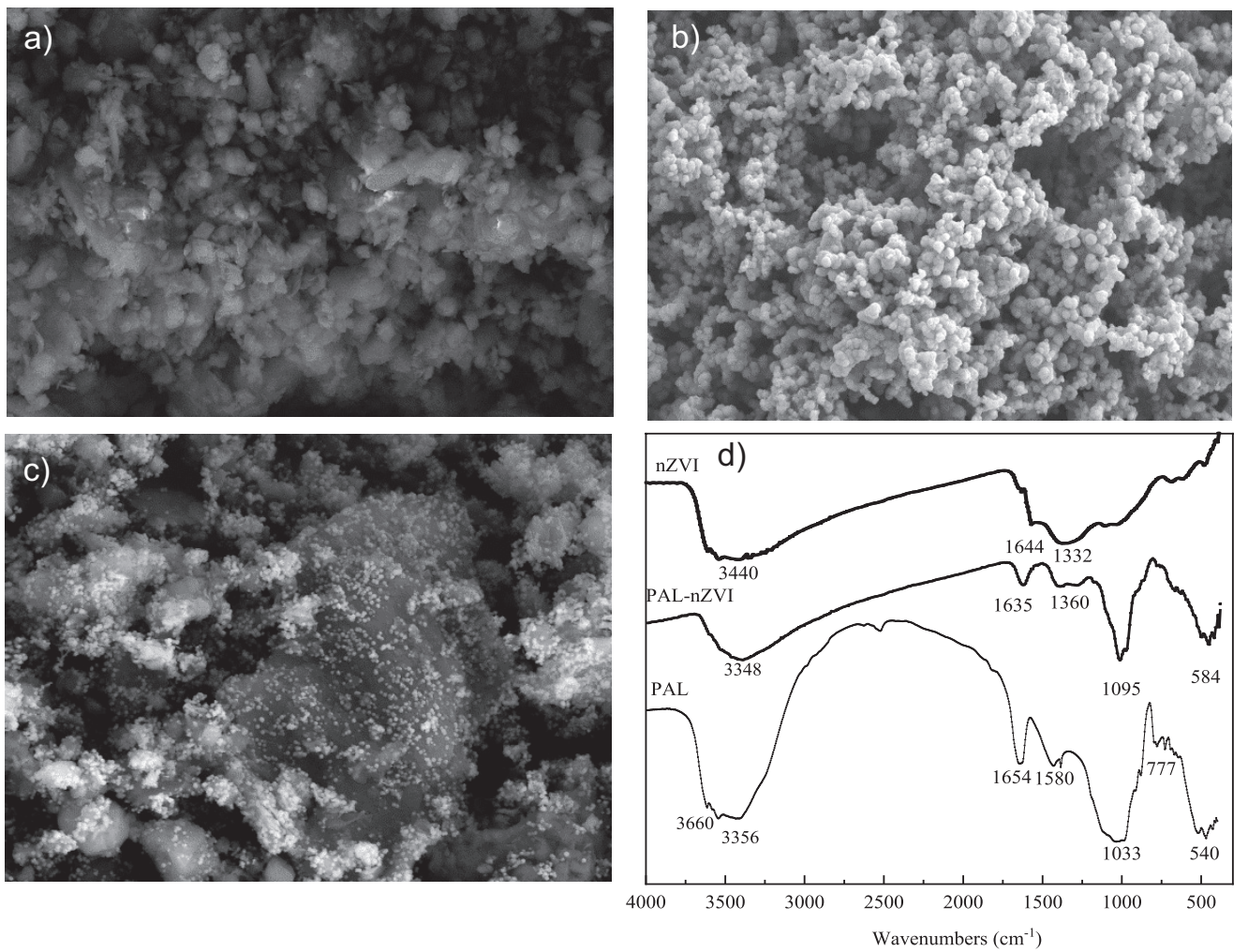

Fig. 2. SEM images of a) palygoskite, b) nZVI, c) PAL-nZVI, d) FTIR spectra of samples.

Fig. 2d) presents the FTIR spectra of PAL, nZVI, PAL-nZVI, which could reveal the functional groups of these materials. The $\mathrm{O}-\mathrm{H}$ stretching vibration peak at $3348 \mathrm{~cm}^{-1}$ in PAL-nZVI was indicated that the hydrogen bonds had occurred between palygorskite and nZVI and the $\mathrm{Si}-\mathrm{OH}$ and $\mathrm{Fe}-\mathrm{OH}$ existed on the PAL-nZVI surface. Peaks at $3440 \mathrm{~cm}^{-1}$ of nZVI result from the formation of FeOOH on the surface of nZVI [35]. The peak at $1620-1644 \mathrm{~cm}^{-1}$ associated with the stretching vibration in the adsorbed water molecules. The iron oxyhydroxide had formed on the surface of nZVI and PAL-nZVI, the distinctive stretching vibration peak at 1360-1332 $\mathrm{cm}^{-1}$ could detect in nZVI and PAL-nZVI but were not detected in palygorskite [37]. The peak at 1033, 777 and $540 \mathrm{~cm}^{-1}$ could result from stretching and transformation of $\mathrm{Si}-\mathrm{O}-\mathrm{Si}, \mathrm{Al}-\mathrm{O}-\mathrm{Si}$ in palygorskite, which were changed for the weaker bonds of Si-O-Fe and $\mathrm{FeOOH}$ in PAL-nZVI. Consequently, plenty of functional groups, such as hydroxyl, $\mathrm{Fe}-\mathrm{O}$ and $\mathrm{FeOOH}$ were generated on the surface of PAL-nZVI, which could supply a large number of active sites for the complexation of heavy metals.

\section{Changes of Physicochemical Properties}

$\mathrm{pH}$ played an essential role in controlling the transfer behavior of heavy metals in soil [38]. We could see from Fig. 3a) that when the dosage of PAL-nZVI was $0.5 \%$ and $2 \%$, the change of soil $\mathrm{pH}$ was not obvious, while with the further increase of dosage, the $\mathrm{pH}$ of the soil increased significantly. When the dosage of PAL-nZVI was $4 \%, 6 \%$ and $8 \%$, the $\mathrm{pH}$ value of soil increased from $4.68 \pm 0.02$ to $5.24 \pm 0.02,5.89 \pm 0.02$ and $6.05 \pm 0.01$ after 15 days, respectively. After 30 days, the soil pH increased to $6.02 \pm 0.02,6.42 \pm 0.02,6.49 \pm 0.01$, which increased by $1.30,1.70,1.77 \mathrm{pH}$ units than CK. After 45 days, the soil $\mathrm{pH}$ increased to $6.21 \pm 0.01,6.47 \pm 0.02$, $6.50 \pm 0.02$, which increased by $1.54,1.80,1.83 \mathrm{pH}$ units than CK. In previous research, when added the nZVI to co-contaminated soil, the soil $\mathrm{pH}$ increased by only $0.41 \mathrm{pH}$ units after 42 days [23]. It could be seen that PAL-nZVI can improve the soil $\mathrm{pH}$ significantly and reach a stable station after 30 days. The reason why the $\mathrm{pH}$ value of soil increased was attributed to the corrosion of $\mathrm{Fe}^{0}$ [35]. When the nZVI was oxidation as the following reaction, the $\mathrm{OH}^{-}$ions were released, and the $\mathrm{pH}$ of system was increased significantly.

$$
2 \mathrm{Fe}^{0}+\mathrm{O}_{2}+2 \mathrm{H}_{2} \mathrm{O} \rightarrow 2 \mathrm{Fe}^{2+}+4 \mathrm{OH}^{-}
$$

When the $\mathrm{pH}$ increased, the competition between $\mathrm{H}^{+}$and metal ions became weaker, which was easier for heavy metals to combined into the stable form (such as $\left.\mathrm{Cd}(\mathrm{OH})^{+}, \mathrm{Cd}_{2}(\mathrm{OH})^{3+}, \mathrm{Pb}(\mathrm{OH})^{+}, \mathrm{Pb}_{2}(\mathrm{OH})^{3+}\right)$ on the surface of iron (oxyhydro) oxide, therefore entrapment the $\mathrm{Cd}$ and $\mathrm{Pb}$ on the surface of PAL-nZVI particles.

As we all know, soil CEC was associated with the negative charge in soil. The more negatively charged sorption sites on the soil, the greater the soil CEC. At high soil $\mathrm{pH}$, more negative charges had been carried on the surface of nZVI, and the CEC was increased with the application of PAL-nZVI. From Fig. 3b), after 
a)

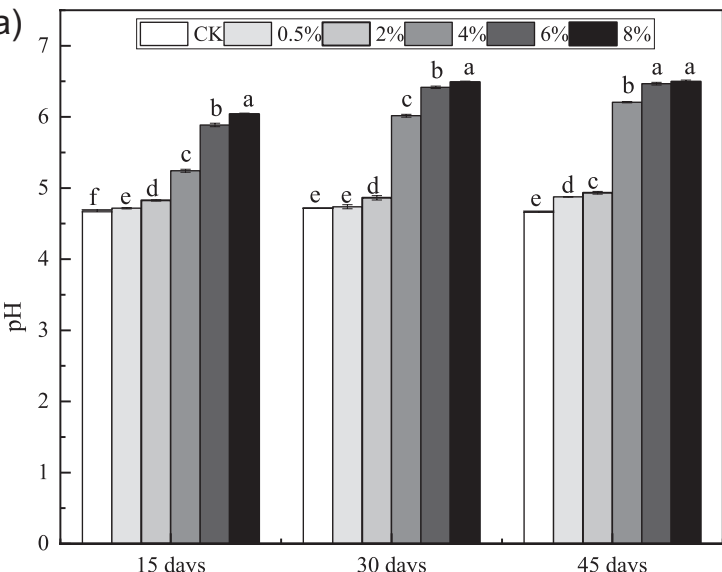

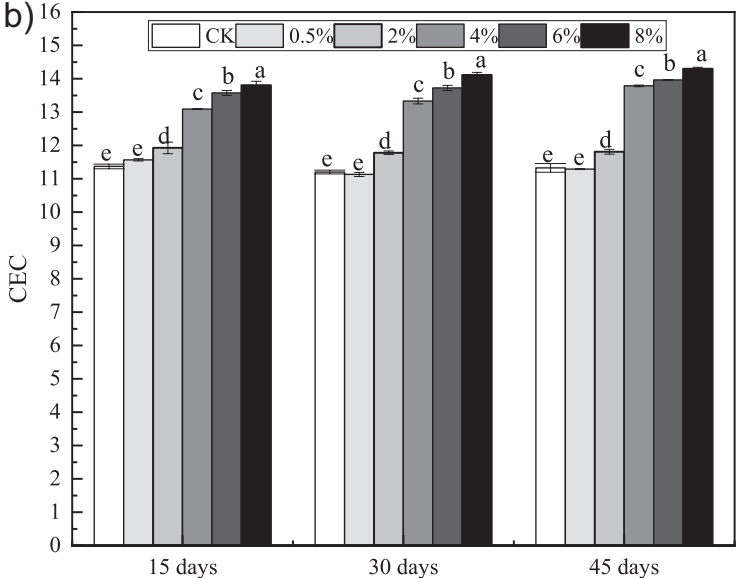

Fig. 3. The change of soil $\mathrm{pH}$ a) and CEC b) under different dosage of PAL-nZVI at various treatment time. Error bars indicate standard deviation $(\mathrm{n}=3)$.

15 days, the CEC increased by $1.73 \%, 4.90 \%, 15.13 \%$, $19.38 \%, 21.40 \%$ treated by PAL-nZVI $(0.5 \%, 2 \%, 4 \%$, $6 \%, 8 \%$ ) than CK. After 45 days, the CEC increased by $0.35 \%, 4.24 \%, 21.68 \%, 23.24 \%, 26.21 \%$ treated by PALnZVI $(0.5 \%, 2 \%, 4 \%, 6 \%, 8 \%)$ than CK. This finding was similar to that of Zhai [39], who reported that the soil CEC had a positive correlation between $\mathrm{pH}$ and could alleviate the toxic effect of heavy metals in soil.

\section{$\mathrm{CaCl}_{2}$-Extractable $\mathrm{Cd}$ and $\mathrm{Pb}$}

Fig. 4 showed the effect of remediation time and the amendment dosage on $\mathrm{CaCl}_{2}$-extractable $\mathrm{Cd}$ and $\mathrm{Pb}$. We found from Fig. 4a) and b), that when the soil samples were treated with PAL-nZVI for 30 days, the $\mathrm{CaCl}_{2}$-extractable $\mathrm{Cd}$ decreased from its original $3.11 \pm 0.07 \mathrm{mg} / \mathrm{kg}$ to $2.80 \pm 0.00,2.58 \pm 0.09,1.32 \pm 0.15$, $1.30 \pm 0.04,1.29 \pm 0.03 \mathrm{mg} / \mathrm{kg}$ when the dosage was $0.5 \%$, $2 \%, 4 \%, 6 \%$ and $8 \%$, respectively. The immobilization efficiency increased to $57.66 \%, 58.20 \%, 58.63 \%$ when the dosage was $4 \%, 6 \%$ and $8 \%$, respectively after 30 days of incubation. The immobilization efficiency was increased by $35.00 \%, 22.87 \%, 21.20 \%$ from $15^{\text {th }}$ to 30 th days, and increased by only $1.38 \%, 4.76 \%, 5.60 \%$ from $30^{\text {th }}$ to $45^{\text {th }}$ days when the dosage was $4 \%, 6 \%$ and $8 \%$, respectively.

From Fig. 4c) and d), we could see that the concentration of $\mathrm{CaCl}_{2}$-extractable $\mathrm{Pb}$ in the untreated soil was $4.72 \mathrm{mg} / \mathrm{kg}$. With the increasing dosage of PAL-nZVI, the concentrations of $\mathrm{CaCl}_{2}$-extractable $\mathrm{Pb}$ were reduced significantly. When $4 \%, 6 \%$ and $8 \%$ PALnZVI was applied into the soil, the $\mathrm{CaCl}_{2}$-extractable $\mathrm{Pb}$ decreased from its original $59.43 \pm 4.88 \mathrm{mg} / \mathrm{kg}$ to $8.23 \pm 0.53,6.73 \pm 0.31,6.89 \pm 0.05 \mathrm{mg} / \mathrm{kg}$, respectively, and the immobilization efficiency increased to $86.16 \%, 88.67 \%, 88.76 \%$ at 30 days. After 45 days, the immobilization efficiency had been nearly reached the equilibrium point and increased only $2.82 \%$, $1.03 \%, 1.43 \%$ when the dosage was $4 \%, 6 \%$ and $8 \%$, respectively.
With the increase of PAL-nZVI, the greater adsorption sites provided to heavy metals and tended to remain constant with that of the dosage of $8 \%$. It was concluded that the 30 days was a critical period for $\mathrm{Cd}$ and $\mathrm{Pb}$ stabilization and the optimum dosage of PAL-nZVI was $6 \%$. Li et al. used to apply the zeolite-supported nanoscale zero-valent iron to cocontaminated soil and the $\mathrm{CaCl}_{2}$-extractable $\mathrm{Cd}$ and $\mathrm{Pb}$ reduced by $30 \%$ and $64 \%$, respectively [10]. These results above suggested that the PAL-nZVI was an effective stabilizer for the bio-availability of $\mathrm{Cd}$ and $\mathrm{Pb}$ in multi-contaminated soil.

\section{TCLP Method}

The TCLP leachability concentration of $\mathrm{Cd}$ and $\mathrm{Pb}$ stipulated by the U.S. Environmental Protection Agency (USEPA1992) was $0.5 \mathrm{mg} / \mathrm{L}$ and $5 \mathrm{mg} / \mathrm{L}$. As shown in Fig. 5, the TCLP leachability of $\mathrm{Cd}$ and $\mathrm{Pb}$ in the CK were detected to be 0.21 and $2.25 \mathrm{mg} / \mathrm{L}$, which were both below the limits value of standard but still had the potential toxicity for the human beings. The TCLP leachability concentration of $\mathrm{Cd}$ and $\mathrm{Pb}$ were decreased significantly in the soil remediated with PAL-nZVI. The addition of PAL-nZVI at the dosage of $6 \%$, markedly decreased the TCLP leachability concentration of $\mathrm{Cd}$ from $0.22 \pm 0.00 \mathrm{mg} / \mathrm{L}$ to $0.07 \pm 0.01 \mathrm{mg} / \mathrm{L}$ and $\mathrm{Pb}$ from $2.53 \pm 0.04 \mathrm{mg} / \mathrm{L}$ to $1.12 \pm 0.05 \mathrm{mg} / \mathrm{L}$ at 30 days. The immobilization efficiency increased by $66.98 \%$ and $48.39 \%$ than CK. This result could be explained by excess negative charges, small particle size, high mineral ash contents and a large number of functional groups on the surface of PAL-nZVI. Furthermore, the application of PAL-nZVI was proved more effective in reducing of TCLP Cd than $\mathrm{Pb}$. It may because the $\mathrm{Cd}(\mathrm{OH})_{2}$ had the low solubility relatively and high hydrolysis content of $\mathrm{Cd}^{2+}$ was exist in the soil, which could inhibit the $\mathrm{Pb}$ adsorption at the same active sites. It was in accordance with Fajardo, who reported that the nZVI could decease the TCLP $\mathrm{Cd}$ and $\mathrm{Pb}$ in soil, particularly for $\mathrm{Cd}$. 

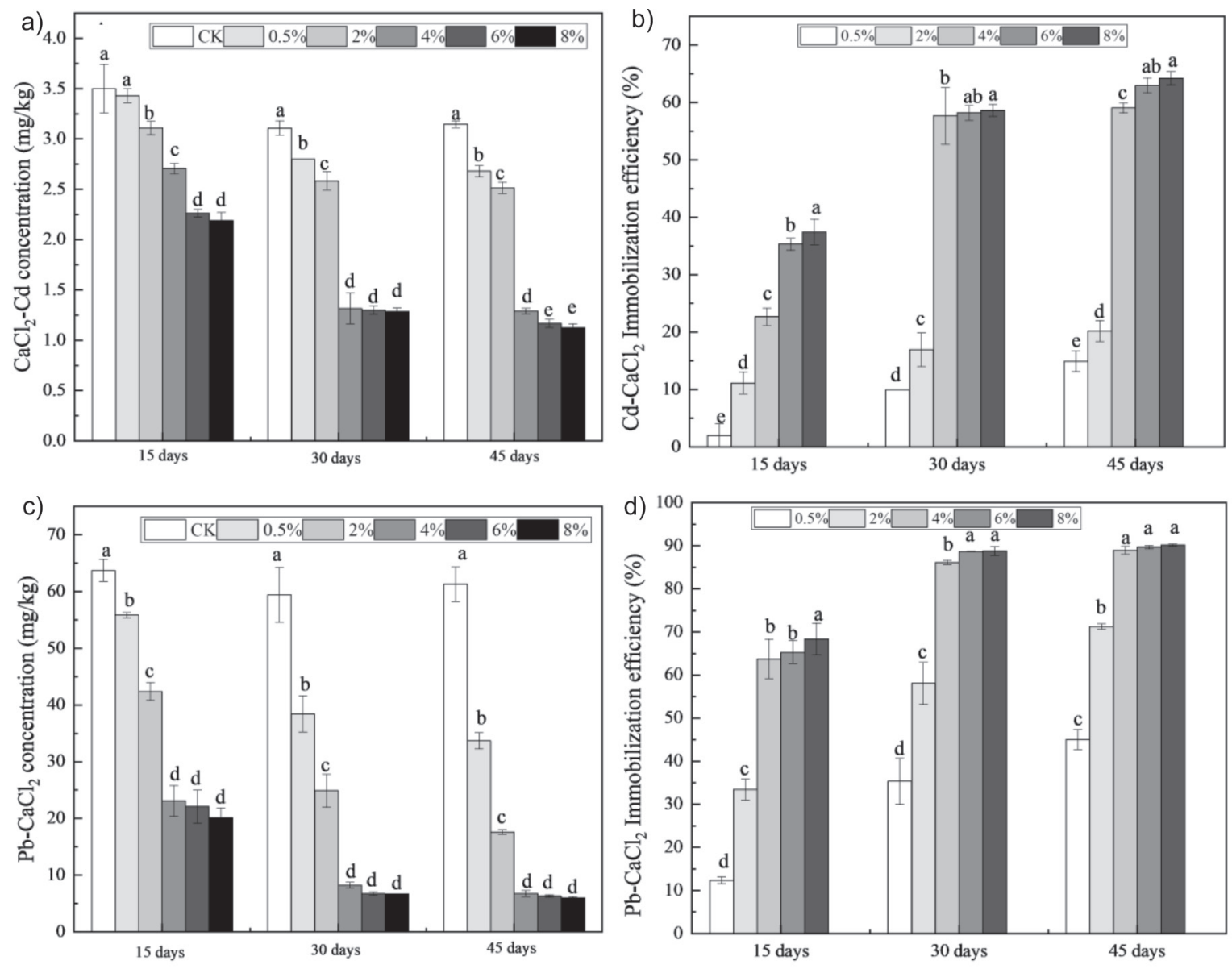

Fig. 4. The $\mathrm{CaCl}_{2}$-extractable $\mathrm{Cd} / \mathrm{Pb}$ and immobilization efficiency at various dosage of PAL-nZVI when the soil samples were treated by the different treatment time. Error bars indicate the standard deviation $(n=3)$ and the same letters indicated the significant differences between treatments at $\mathrm{p}<0.05$

Besides, the treatment time would also be an essential factor in increasing the immobilization efficiency of $\mathrm{Cd}$ and $\mathrm{Pb}$. After PAL-nZVI was added into the soil, it needed some time to disperse in the soil and come into full contact with the heavy metals. Hence, it was necessary to prolong the stabilization time to enhance the immobilization efficiency of $\mathrm{Cd}$ and $\mathrm{Pb}$ [40]. When the dosage of PAL-nZVI increased to $8 \%$, the TCLP leachability concentration of $\mathrm{Cd}$ and $\mathrm{Pb}$ tended to remain unchanged and the equilibrium was almost at 30 days. Obvious, the immobilization of $\mathrm{Cd}$ and $\mathrm{Pb}$ in contaminated soil was slow and complicated, which was unlike the fast adsorption process of heavy metals by nZVI or modified nZVI in aqueous solutions [5].

\section{Speciation of $\mathrm{Cd}$ and $\mathrm{Pb}$ in Soil}

We could see evidence that the speciation of $\mathrm{Cd}$ and $\mathrm{Pb}$ in soil changed greatly after stabilization (Fig. 6). From Fig. 6a), we found that the acid soluble fraction was the dominant speciation of $\mathrm{Cd}$ in the contaminated soil. It accounted for $64.28 \%$ of the total concentration in original soil. After 15 days of stabilization, the acid soluble fraction decreased by $2.35 \%, 7.40 \%, 11.55 \%$,
$18.21 \%, 21.76 \%$ than CK, decreased by $4.74 \%, 12.00 \%$, $22.01 \%, 29.50 \%, 29.92 \%$ than CK after 30 days, and decreased by $4.26 \%, 14.67 \%, 25.12 \%, 29.93 \%, 32.26 \%$ than CK after 45 days when the dosage of PAL-nZVI was $0.5 \%, 2 \%, 4 \%, 6 \%, 8 \%$, respectively. We could see that after 30 days, the change of $\mathrm{Cd}$ speciation tended to stabilize. Compared to CK, the percentage of residual fraction increased from $13.50 \%$ to $15.45 \%$, $24.51 \%, 34.23 \%, 40.74 \%, 40.84 \%$ with the treatment of PAL-nZVI $(0.5 \%, 2 \%, 4 \%, 6 \%, 8 \%)$ after 30 days of stabilization, respectively, which indicated that the toxicity of the $\mathrm{Cd}$ alleviated directly [23]. For $\mathrm{Pb}$, as shown in Fig. 6b), it was mainly distributed in the reducible fraction in the contaminated soil, which took up to $74.07 \%$ in CK. The residual fraction of $\mathrm{Pb}$ increased by $4.93 \%, 17.78 \%, 28.93 \%, 33.75 \%, 36.57 \%$ than CK after 30 days of stabilization. Additionally, when the dosage of PAL-nZVI was $6 \%$ and $8 \%$, the residual fraction of $\mathrm{Cd}$ and $\mathrm{Pb}$ both increased significantly and simultaneously. Consider the cost of remediation and the introduction of exotic $\mathrm{Fe}$ into the soil, so we choose the $6 \%$ of PAL-nZVI as the optimum dosing. We could demonstrate clearly that the $\mathrm{Cd}$ and $\mathrm{Pb}$ both converted from the active speciation to stable 

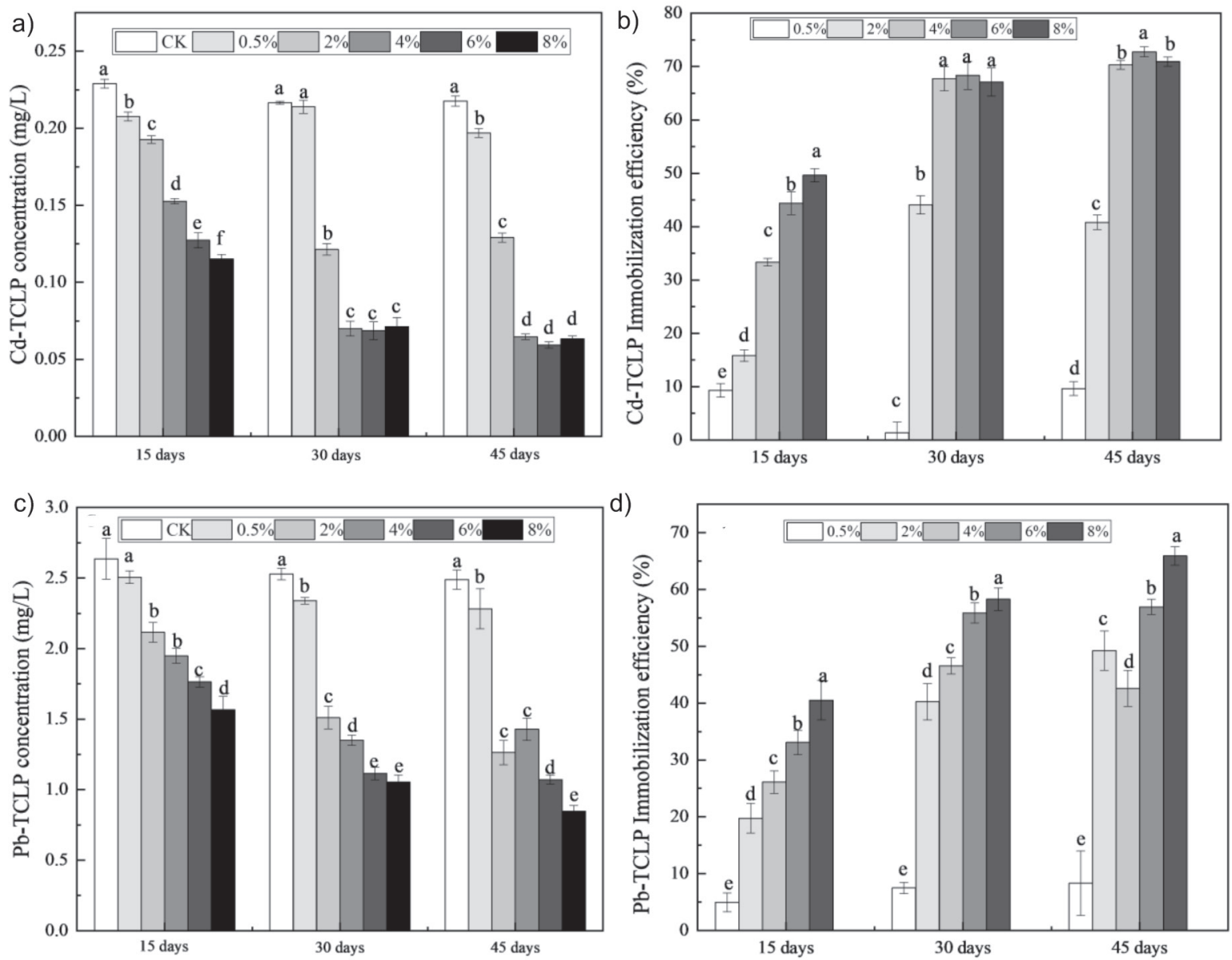

Fig. 5. The TCLP leachability concentration of $\mathrm{Cd} / \mathrm{Pb}$ and immobilization efficiency at various dosage of PAL-nZVI when the soil samples were treated by the different treatment time. Error bars indicate the standard deviation $(n=3)$ and the same letters indicated the significant differences between treatments at $\mathrm{p}<0.05$.

speciation after adding the PAL-nZVI in the soil. This phenomenon could explain as follow: after applying the PAL-nZVI, a layer of the iron oxyhydroxide $(\mathrm{FeOOH})$ could be formed on the surface of PAL-nZVI due to the oxidation of iron, which provided the active sites to complexing with $\mathrm{Cd}$ in the soil. Meanwhile, $\mathrm{Pb}$ (II) should be precipitated to form the $\mathrm{Pb}(\mathrm{OH})_{2}$ after be oxidized. The reaction could occur via the following equations [23]:

$$
\begin{gathered}
\mathrm{FeO}+\mathrm{Cd}^{2+} \rightarrow \mathrm{FeOCd}^{+} \\
\mathrm{FeOH}+\mathrm{Cd}^{2+}+\mathrm{H}_{2} \mathrm{O} \rightarrow \mathrm{FeOCdOH}+\mathrm{H}^{+} \\
\mathrm{Pb}^{2+}+\mathrm{O}_{2} \rightarrow \mathrm{PbO}_{2} \\
\mathrm{PbO}_{2}+\mathrm{OH}^{-} \rightarrow \mathrm{Pb}(\mathrm{OH})_{2} \downarrow
\end{gathered}
$$

The formed $\mathrm{FeOCd}^{+}, \mathrm{FeOCdOH}, \mathrm{Pb}(\mathrm{OH})_{2}$ were relatively stable and could be regarded as the residual fraction, which would be adsorbed and utilized difficultly by biology [20]. What's more, $\mathrm{H}^{+}$appeared during the reaction between $\mathrm{FeOOH}$ and $\mathrm{Cd}$ (Eq. (9)), the surface $-\mathrm{OH}$ might be protonated to form $\mathrm{OH}_{2}^{+}$, which could provide more and stronger active sites to adsorb the heavy metals. On the other hand, due to the difference in the standard potential between lead $(-0.13 \mathrm{~V})$ and zero-valent iron $(-0.41 \mathrm{~V})$, the mechanism of $\mathrm{Pb}$ (II) stabilized by nZVI included the direct reduction in addition to adsorption and the formation of complexes. The standard potential of cadmium is -0.40 $\mathrm{V}$, which is very close to that of $\mathrm{Fe}^{0}$. Therefore, the mechanism of Cd (II) stabilized by nZVI consist of the sorption and complex formation [17]. Furthermore, a large number of functional groups (such as $\mathrm{Si}-\mathrm{O}, \mathrm{C}=\mathrm{O}$ ) also composed the structure of palygoskite, which could form the ligand with $\mathrm{Cd}$ and $\mathrm{Pb}$ in the contaminated soil [26].

The potential risk of heavy metals was also influenced by the distribution of their speciation in the soil. When the metal turned from an active fraction to a stable fraction, the risk that the metal released to the environment weakened considerably, and the metals would hardly remove from soils. According to the potential ecological risk index shown in Table 2, we could see that in this co-contaminated soil, Cd posed a very high risk to the environment. After 15 days, $\mathrm{E}_{\mathrm{r}}^{\mathrm{Cd}}$ 

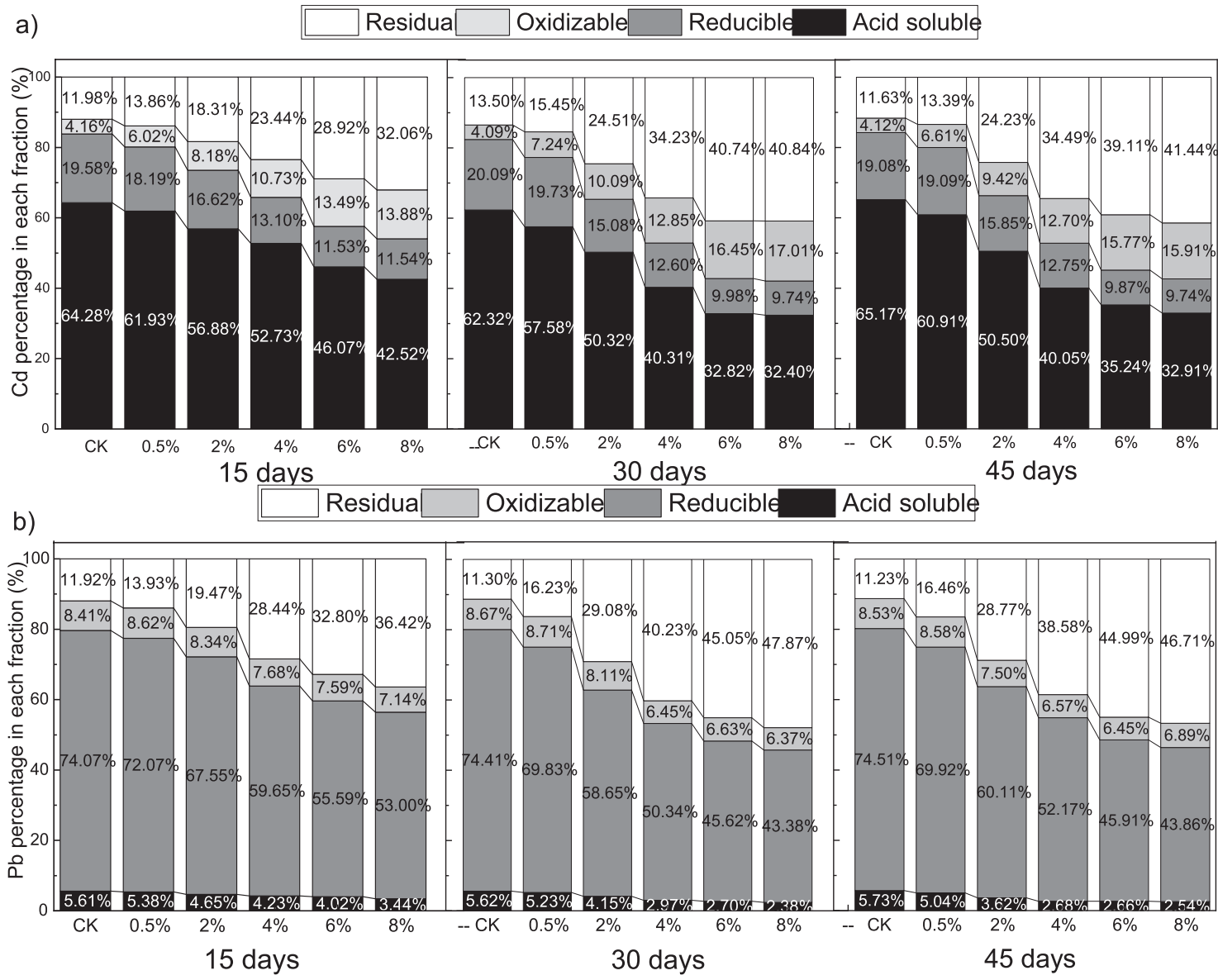

Fig. 6. The speciation of $\mathrm{Cd}$ and $\mathrm{Pb}$ in soil at various dosage of PAL-nZVI when the soil samples were treated by the different treatment time. a) Speciation of $\mathrm{Cd}$; b) Speciation of $\mathrm{Pb}$.

index reduced by $28.79 \%$ and $30.40 \%$ when the dosage of PAL-nZVI increased to $6 \%$ and $8 \%$, respectively. After 30 days, $\mathrm{E}_{\mathrm{r}}^{\mathrm{Cd}}$ index was reduced by $35.13 \%$ and $33.77 \%$ when the dosage of PAL-nZVI increased to $6 \%$ and $8 \%$, respectively. After 45 days, $\mathrm{E}_{\mathrm{r}}^{\mathrm{Cd}}$ index was reduced by $37.15 \%$ and $39.34 \%$ when the dosage of PAL-nZVI increased to $6 \%$ and $8 \%$, respectively. In addition, $\mathrm{Pb}$ had a low potential ecological risk to the environment. In the original soil, $\mathrm{E}_{\mathrm{r}}^{\mathrm{Pb}}$ index was around 5.2, while it could drop below 3.0 after adding the PAL-nZVI. The same results were reported by $\mathrm{Cao}$ [18]. Although the total $\mathrm{Cd}$ and $\mathrm{Pb}$ concentration in soil did not change, while after adding the PALnZVI, the residual fraction increased and the sum of acid soluble, reducible and oxidization fraction of $\mathrm{Cd}$ and $\mathrm{Pb}$ decreased. The release risk of $\mathrm{Cd}$ and $\mathrm{Pb}$ to the

Table 2. Potential risk $\left(\mathrm{E}_{\mathrm{r}}\right)$ of $\mathrm{Cd}$ and $\mathrm{Pb}$ at various dosage of PAL-nZVI when the soil samples were treated by the different treatment time.

\begin{tabular}{|c|c|c|c|c|c|c|c|}
\hline \multirow{2}{*}{ Days } & \multirow{2}{*}{$\mathrm{E}_{\mathrm{r}}$} & \multicolumn{6}{|c|}{ PAL-nZVI dose in \% } \\
\cline { 3 - 8 } & & 0 & 0.5 & 2 & 4 & 6 & 8 \\
\hline \multirow{3}{*}{15} & $\mathrm{Cd}$ & $1203.11 \pm 16.20 \mathrm{a}$ & $1199.96 \pm 6.97 \mathrm{a}$ & $1099.62 \pm 11.21 \mathrm{~b}$ & $994.84 \pm 14.17 \mathrm{c}$ & $856.69 \pm 9.82 \mathrm{~d}$ & $837.38 \pm 21.70 \mathrm{~d}$ \\
\cline { 2 - 9 } & $\mathrm{Pb}$ & $5.25 \pm 0.03 \mathrm{a}$ & $4.95 \pm 0.10 \mathrm{~b}$ & $4.71 \pm 0.03 \mathrm{c}$ & $4.29 \pm 0.08 \mathrm{~d}$ & $3.92 \pm 0.05 \mathrm{e}$ & $3.67 \pm 0.00 \mathrm{f}$ \\
\hline \multirow{2}{*}{30} & $\mathrm{Cd}$ & $1183.24 \pm 30.05 \mathrm{a}$ & $1110.56 \pm 13.60 \mathrm{~b}$ & $1051.73 \pm 3.59 \mathrm{c}$ & $906.73 \pm 27.78 \mathrm{~d}$ & $767.51 \pm 27.11 \mathrm{e}$ & $783.67 \pm 11.48 \mathrm{e}$ \\
\cline { 2 - 9 } & $\mathrm{Pb}$ & $5.22 \pm 0.03 \mathrm{a}$ & $4.83 \pm 0.12 \mathrm{~b}$ & $4.00 \pm 0.02 \mathrm{c}$ & $3.56 \pm 0.07 \mathrm{~d}$ & $3.15 \pm 0.07 \mathrm{e}$ & $2.91 \pm 0.08 \mathrm{f}$ \\
\hline \multirow{2}{*}{45} & $\mathrm{Cd}$ & $1237.58 \pm 17.43 \mathrm{a}$ & $1176.38 \pm 2.89 \mathrm{~b}$ & $985.02 \pm 22.25 \mathrm{c}$ & $842.49 \pm 6.48 \mathrm{~d}$ & $777.80 \pm 26.17 \mathrm{e}$ & $750.71 \pm 16.45 \mathrm{e}$ \\
\cline { 2 - 9 } & $\mathrm{Pb}$ & $5.28 \pm 0.02 \mathrm{a}$ & $4.71 \pm 0.08 \mathrm{~b}$ & $4.22 \pm 0.08 \mathrm{c}$ & $3.61 \pm 0.07 \mathrm{~d}$ & $3.11 \pm 0.06 \mathrm{e}$ & $2.90 \pm 0.06 \mathrm{f}$ \\
\hline
\end{tabular}

$\mathrm{E}_{\mathrm{r}}^{\mathrm{Cd}}$ and $\mathrm{E}_{\mathrm{r}}^{\mathrm{Pb}}$ were calculated by the $\mathrm{Eq} .3$. The non-residual metal fraction content (sum of acid soluble, reducible and oxidization fraction of the $\mathrm{Cd}$ and $\mathrm{Pb}$ ) in soils were chosen as the $\mathrm{C}_{\mathrm{r}}^{\mathrm{Cd}}$ and $\mathrm{C}_{\mathrm{r}}^{\mathrm{Pb}}$. 
environment was weakened dramatically by reducing the concentration of labile metal speciation and increasing the strongly bound speciation.

\section{Plant Growth and Metal Bioavailability}

\section{Effects on Plant Growth}

The effect of PAL-nZVI on the growth situation of corn was shown in Fig. 7. PAL-nZVI could significantly improve the growth of the plant. The length, fresh weight and dry weight of corn all increased simultaneously, and the more PAL-nZVI that was applied, the better the corn grew. Compared with the CK, the corn's length of root increased by $228.48 \%, 222.76 \%, 234.19 \%$, and the corn's length of shoot increased by $118.78 \%, 107.84 \%$, $120.35 \%$ when the dosage of PAL-nZVI was $4 \%, 6 \%$, $8 \%$, respectively. The fresh weight of corn increased by $33.87 \%, 65.58 \%, 169.12 \%, 189.99 \%$ and $185.68 \%$ with the addition of $0.5,2,4,6,8 \%$ PAL-nZVI, respectively. The dry weight of corn had the same increase trend, and the growth rate up to $169.2 \%$ compared with CK when the dosage of PAL-nZVI was $6 \%$. It could be seen that when the addition of PAL-nZVI was great than $4 \%$ in contaminated soil, it would have an obvious promoting effect on the growth of plants. However, when the addition of PAL-nZVI increased from $6 \%$ to $8 \%$, the biomass of corn increased not significant. The plant's resistance to the $\mathrm{Cd}$ and $\mathrm{Pb}$ stress in soil was enhanced when applied the PAL-nZVI in contaminated soil, and the stress generated by the toxicity of heavy metals was decreased for the plant.

\section{Accumulation and Translocation of $\mathrm{Cd}$ and $\mathrm{Pb}$ by Plant}

The remediation effect of the amendment for $\mathrm{Cd}$ and $\mathrm{Pb}$-contaminated soil was aimed at decreasing
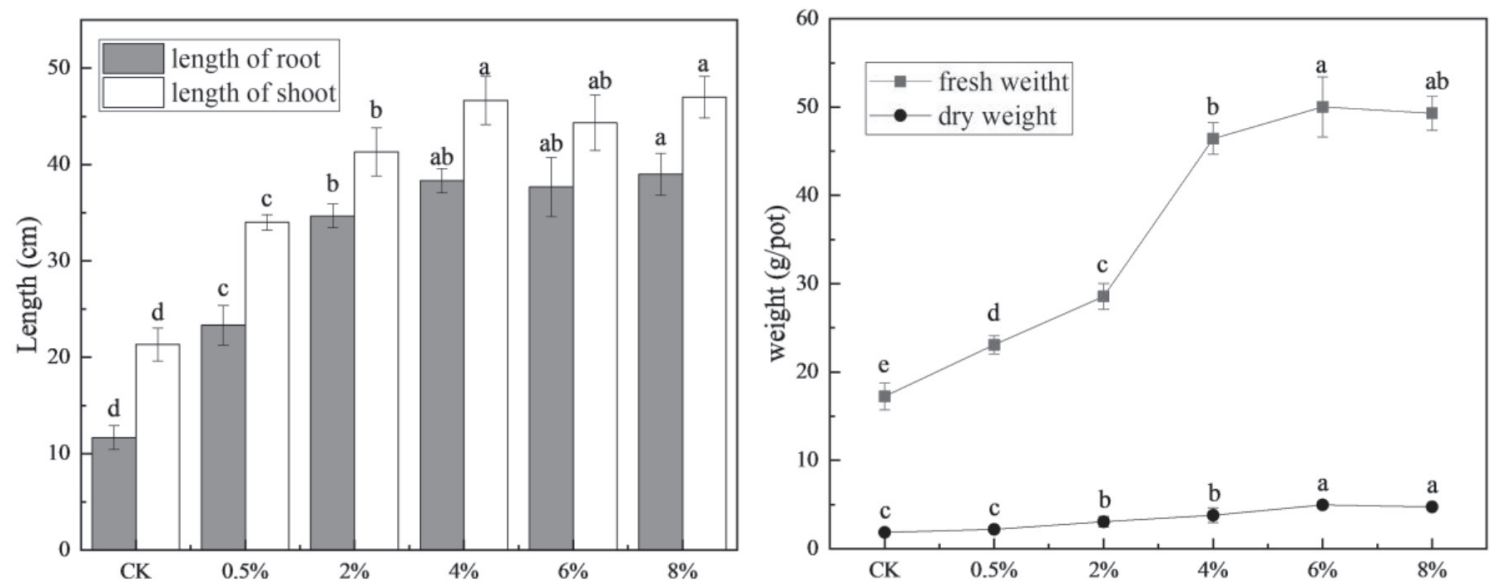

Fig. 7. The length and biomass of shoot and root part of corn grown in the soil amended with the various dosage of PAL-nZVI. The different letter $(a, b, c)$ within the same column indicate significant differences at $\mathrm{P}<0.05$.
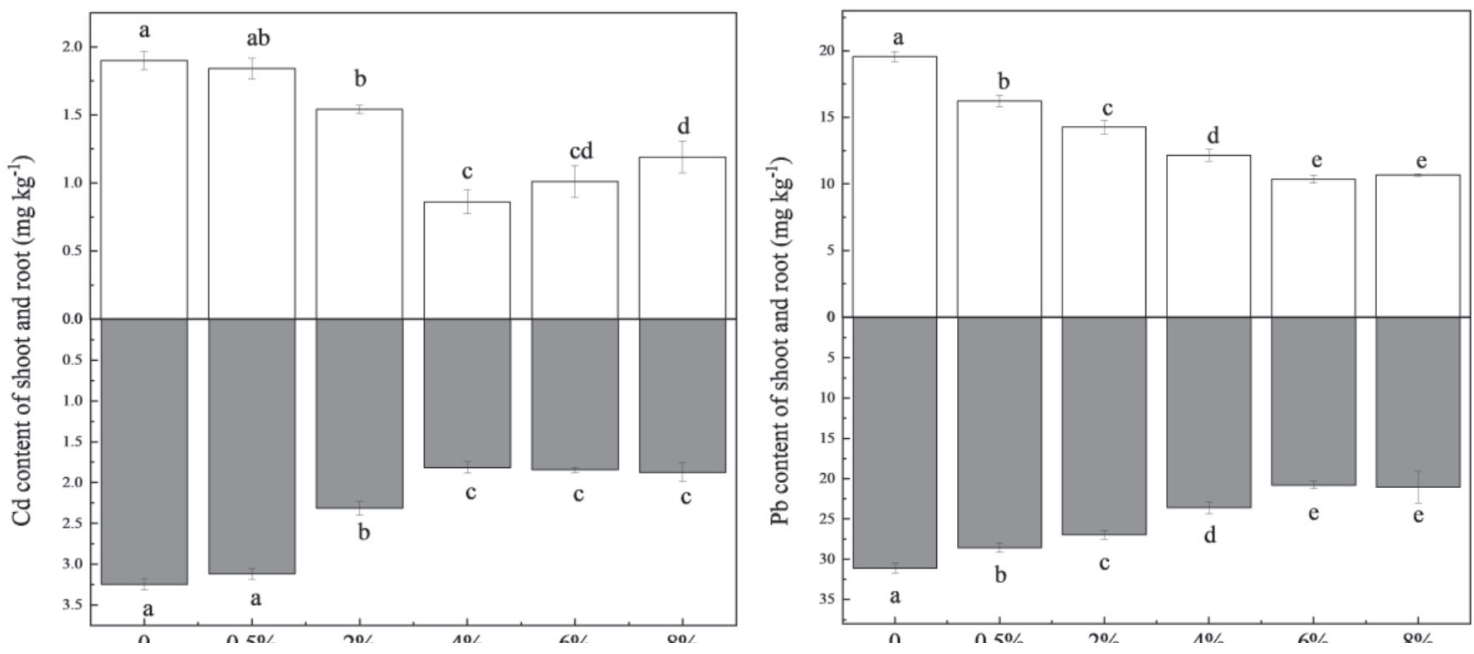

Fig. 8. $\mathrm{Cd}$ and $\mathrm{Pb}$ contents of roots (lower part) and shoots (upper part) at various dosage of PAL-nZVI. Data are means $\pm \mathrm{SD}(\mathrm{n}=3)$. Bars with different letter $(\mathrm{a}, \mathrm{b}, \mathrm{c})$ within the same column indicate significant differences at $\mathrm{P}<0.05$. 
Table 3. BCF and TF of $\mathrm{Cd}$ and $\mathrm{Pb}$ in plants at various dosage of PAL-nZVI.

\begin{tabular}{|c|c|c|c|c|c|c|}
\hline \multirow{2}{*}{$\begin{array}{c}\text { PAL-nZVI } \\
\text { dose in \% }\end{array}$} & \multicolumn{4}{|c}{$\mathrm{Cd}$} & \multicolumn{2}{c|}{$\mathrm{Pb}$} \\
\cline { 2 - 7 } & $\mathrm{BCF}_{\text {shoot }}$ & $\mathrm{BCF}_{\text {root }}$ & $\mathrm{TF}$ & $\mathrm{BCF}_{\text {shoot }}$ & $\mathrm{BCF}_{\text {root }}$ & $\mathrm{TF}$ \\
\hline 0 & $0.099 \pm 0.003 \mathrm{a}$ & $0.171 \pm 0.004 \mathrm{a}$ & $0.586 \pm 0.011 \mathrm{ab}$ & $0.208 \pm 0.004 \mathrm{a}$ & $0.330 \pm 0.006 \mathrm{a}$ & $0.629 \pm 0.002 \mathrm{a}$ \\
\hline 0.5 & $0.097 \pm 0.004 \mathrm{a}$ & $0.164 \pm 0.004 \mathrm{a}$ & $0.590 \pm 0.013 \mathrm{ab}$ & $0.172 \pm 0.005 \mathrm{~b}$ & $0.303 \pm 0.006 \mathrm{~b}$ & $0.568 \pm 0.008 \mathrm{~b}$ \\
\hline 2 & $0.081 \pm 0.001 \mathrm{~b}$ & $0.121 \pm 0.005 \mathrm{~b}$ & $0.666 \pm 0.014 \mathrm{ab}$ & $0.151 \pm 0.005 \mathrm{c}$ & $0.286 \pm 0.006 \mathrm{~b}$ & $0.529 \pm 0.029 \mathrm{bc}$ \\
\hline 4 & $0.045 \pm 0.005 \mathrm{~d}$ & $0.095 \pm 0.004 \mathrm{c}$ & $0.472 \pm 0.042 \mathrm{~b}$ & $0.129 \pm 0.005 \mathrm{~d}$ & $0.251 \pm 0.008 \mathrm{c}$ & $0.515 \pm 0.034 \mathrm{bc}$ \\
\hline 6 & $0.053 \pm 0.006 \mathrm{~cd}$ & $0.097 \pm 0.002 \mathrm{c}$ & $0.548 \pm 0.055 \mathrm{ab}$ & $0.110 \pm 0.003 \mathrm{e}$ & $0.221 \pm 0.005 \mathrm{~d}$ & $0.498 \pm 0.005 \mathrm{c}$ \\
\hline 8 & $0.063 \pm 0.006 \mathrm{c}$ & $0.099 \pm 0.006 \mathrm{c}$ & $0.634 \pm 0.101 \mathrm{a}$ & $0.113 \pm 0.001 \mathrm{e}$ & $0.224 \pm 0.021 \mathrm{~d}$ & $0.506 \pm 0.049 \mathrm{bc}$ \\
\hline
\end{tabular}

the accumulation and migration of $\mathrm{Cd}$ and $\mathrm{Pb}$ by the plant. To further estimate the stabilization efficiency of the PAL-nZVI on $\mathrm{Cd}$ and $\mathrm{Pb}$ in soil, the uptake and translocation of $\mathrm{Cd}$ and $\mathrm{Pb}$ in the corn grown in contaminated soil were measured. As shown in Fig. 8, the accumulation of $\mathrm{Cd}$ and $\mathrm{Pb}$ by corn reduced significantly compared to the $\mathrm{CK}$ when applied the PAL-nZVI in soil. The concentration of $\mathrm{Cd}$ in the shoot part of corn decreased by $3.16 \%, 18,95 \%, 54.91 \%$, $46.84 \%$, and $37.37 \%$, respectively, and the root part of corn decreased by $4.1 \%, 28.82 \%, 44.10 \%, 43.28 \%$, and $42.26 \%$, respectively, compared to $\mathrm{CK}$ when the dosage of PAL-nZVI was $0.5 \%, 2 \%, 4 \%, 6 \%$, $8 \%$. Simultaneously, the content of $\mathrm{Pb}$ decreased by $47.11 \%$ in the shoot part and $33.12 \%$ in the root part of corn with the $6 \%$ addition of PAL-nZVI. Nevertheless, adding more than 6\% PAL-nZVI could not further decrease the $\mathrm{Cd}$ and $\mathrm{Pb}$ accumulation in the plant.

Table 3 showed the BCF of the shoot and root part and the TF calculated by Eq. 4 and 5. The $\mathrm{BCF}_{\text {shoot }}$ and $\mathrm{BCF}_{\text {root }}$ of $\mathrm{Cd}$ declined by $47.0 \%$ and $43.3 \%$, $\mathrm{Pb}$ declined by $47.1 \%$ and $33.0 \%$, respectively when the dosage of PAL-nZVI was $6 \%$. However, both the TF of $\mathrm{Cd}$ and $\mathrm{Pb}$ had only reduced slightly. These findings suggested that the PAL-nZVI remediation was efficient from the detoxification opinion [35].

\section{Conclusions}

In this study, palygorskite was used as a carrier for nZVI to synthesize a new type of stabilizer for $\mathrm{Cd}$ and $\mathrm{Pb}$ stabilization from co-contaminated soil. The nZVI could effectively reduce from being aggregated and oxidized after loaded with palygorskite. It distributed on the surface of palygorskite keeps a spherical nanoparticle with the diameter of 40-60 nm. The bioavailability and TCLP leachability of $\mathrm{Cd}$ and $\mathrm{Pb}$ in soil could be decreased significantly $(\mathrm{P}<0.05)$ after it was stabilized by PAL-nZVI with the dosage of $6 \%$ after 30 days. Meanwhile, the speciation of $\mathrm{Cd}$ and $\mathrm{Pb}$ has partially transformed from an unstable fraction into a stable fraction, and the potential risk of $\mathrm{Pb}$ and $\mathrm{Cd}$ decreased significantly in the soil after amended by PAL-nZVI. Adsorption, cation exchange and electrostatic action were the most likely mechanism of $\mathrm{Cd}$ immobilization and the reduction, adsorption, oxidation and precipitation were the most likely mechanism of $\mathrm{Pb}$ immobilization by PAL-nZVI in the soil. Additionally, adding the PAL-nZVI to the soil could promote the growth of corn and reduce its accumulation of $\mathrm{Cd}$ and $\mathrm{Pb}$. Overall, the PAL-nZVI is a low-cost, eco-friendly and easyavailable material that can be a feasible and potential amendment to remediate the $\mathrm{Cd}$ and $\mathrm{Pb}$ contaminated soil effectively.

\section{Acknowledgements}

This research was supported by the National Natural Science Foundation of China (No. 51668034).

\section{Conflict of Interest}

The authors declare no conflict of interest.

\section{References}

1. BASHIR S., SHAABAN M., HUSSAIN Q., MEHMOOD S., ZHU J., FU Q., AZIZ O., HU H. Influence of organic and inorganic passivators on $\mathrm{Cd}$ and $\mathrm{Pb}$ stabilization and microbial biomass in a contaminated paddy soil. J Soil Sediment. 18, 2948, 2018.

2. CHANG Y.T., HSI H.C., HSEU Z.Y., JHENG S.L. Chemical stabilization of cadmium in acidic soil using alkaline agronomic and industrial by-products. J Environ Sci Health A Tox Hazard Subst Environ Eng. 48, 1748, 2013.

3. CUI M., LEE Y., CHOI J., KIM J., HAN Z., SON Y., KHIM J. Evaluation of stabilizing materials for immobilization of toxic heavy metals in contaminated agricultural soils in China. J Clean Prod. 193, 748, 2018.

4. BOLAN N., KUNHIKRISHNAN A., THANGARAJAN R., KUMPIENE J., PARK J., MAKINO T., KIRKHAM M. B., SCHECKEL K. Remediation of heavy metal(loid)s contaminated soils--to mobilize or to immobilize. J Hazard Mater. 266, 141, 2014. 
5. LIU Q., SHENG Y., WANG W., LI C., ZHAO G. Remediation and its biological responses of $\mathrm{Cd}$ contaminated sediments using biochar and minerals with nanoscale zero-valent iron loading. Sci Total Environ. 713, 136650, 2020.

6. GUO F., DING C., ZHOU Z., HUANG G., WANG $X$. Stability of immobilization remediation of several amendments on cadmium contaminated soils as affected by simulated soil acidification. Ecotox Environ Safe. 161, 164, 2018.

7. HU Y., CHENG H., TAO S. The Challenges and Solutions for Cadmium-contaminated Rice in China: A Critical Review. Environ Int. 92-93, 515, 2016.

8. HU B., SHAO S., NI H., FU Z., HU L., ZHOU Y., MIN X., SHE S., CHEN S., HUANG M., ZHOU L., LI Y., SHI Z. Current status, spatial features, health risks, and potential driving factors of soil heavy metal pollution in China at province level. Environ Pollut. 266, 114961, 2020.

9. CUI H., FAN Y., XU L., ZHOU J., ZHOU D., MAO J., FANG G., CANG L., ZHU Z. Sustainability of in situ remediation of $\mathrm{Cu}$ - and $\mathrm{Cd}$-contaminated soils with onetime application of amendments in Guixi, China. J Soil Sediment. 16, 1498, 2015.

10. LI Z., WANG L., MENG J., LIU X., XU J., WANG F., BROOKES P. Zeolite-supported nanoscale zero-valent iron: New findings on simultaneous adsorption of $\mathrm{Cd}(\mathrm{II})$, $\mathrm{Pb}(\mathrm{II})$, and $\mathrm{As}(\mathrm{III})$ in aqueous solution and soil. J Hazard Mater. 344, 1, 2018.

11. NEJAD Z.D., JUNG M.C., KIM K.H. Remediation of soils contaminated with heavy metals with an emphasis on immobilization technology. Environ Geochem Health. 40, 927, 2018.

12. CHEN Y., XIE T., LIANG Q., LIU M., ZHAO M., WANG M., WANG G. Effectiveness of lime and peat applications on cadmium availability in a paddy soil under various moisture regimes. Environ Sci Pollut Res Int. 23, 7757, 2016.

13. MEHMOOD S., RIZWAN M., BASHIR S., DITTA A., AZIZ O., YONG L.Z., DAI Z., AKMAL M., AHMED W., ADEEL M., IMTIAZ M., TU S. Comparative Effects of Biochar, Slag and Ferrous-Mn Ore on Lead and Cadmium Immobilization in Soil. Bull Environ Contam Toxicol. 100, 286, 2018.

14. SUN Y., XU Y., XU Y., WANG L., LIANG X., LI Y. Reliability and stability of immobilization remediation of $\mathrm{Cd}$ polluted soils using sepiolite under pot and field trials. Environ Pollut. 208, 739, 2016.

15. SUN R.J., CHEN J.H., FAN T.T., ZHOU D.M., WANG Y.J. Effect of nanoparticle hydroxyapatite on the immobilization of $\mathrm{Cu}$ and $\mathrm{Zn}$ in polluted soil. Environ Sci Pollut Res Int. 25, 73, 2018.

16. DIAO Z.H., QIAN W., ZHANG Z.W., JIN J.C., CHEN Z.L., GUO P.R., DONG F.X., YAN L., KONG L.J., CHU W. Removals of $\mathrm{Cr}(\mathrm{VI})$ and $\mathrm{Cd}(\mathrm{II})$ by a novel nanoscale zero valent iron/peroxydisulfate process and its Fentonlike oxidation of pesticide atrazine: Coexisting effect, products and mechanism. Chem Eng J. 397, 2020.

17. GUHA T., BARMAN S., MUKHERJEE A., KUNDU R. Nano-scale zero valent iron modulates $\mathrm{Fe} / \mathrm{Cd}$ transporters and immobilizes soil $\mathrm{Cd}$ for production of $\mathrm{Cd}$ free rice. Chemosphere. 260, 127533, 2020.

18. CAO Y., ZHANG S., ZHONG Q., WANG G., XU X., LI T., WANG L., JIA Y., LI Y. Feasibility of nanoscale zerovalent iron to enhance the removal efficiencies of heavy metals from polluted soils by organic acids. Ecotoxicol Environ Saf. 162, 464, 2018.
19. ARANCIBIA M. N., BALTAZAR S.E., GARCíA A., MUÑOZ L.D., SEPúLVEDA P., RUBIO M.A., ALTBIR D. Nanoscale zero valent supported by Zeolite and Montmorillonite: Template effect of the removal of lead ion from an aqueous solution. J Hazard Mater. 301, 371, 2016.

20. HUANG D., HU Z., PENG Z., ZENG G., CHEN G., ZHANG C., CHENG M., WAN J., WANG X., QIN $\mathrm{X}$. Cadmium immobilization in river sediment using stabilized nanoscale zero-valent iron with enhanced transport by polysaccharide coating. J Environ Manage. 210, 191, 2018

21. YANG D., WANG L., LI Z., TANG X., HE M., YANG S., LIU X., XU J. Simultaneous adsorption of Cd(II) andAs(III)by a novel biochar-supported nanoscale zerovalent iron in aqueous systems. Sci Total Environ. 708, 134823, 2020.

22. FU R., YANG Y., XU Z., ZHANG X., GUO X., BI D. The removal of chromium (VI) and lead (II) from groundwater using sepiolite-supported nanoscale zero-valent iron (S-NZVI). Chemosphere. 138, 726, 2015.

23. XUE W., HUANG D., ZENG G., WAN J., ZHANG C., XU R., CHENG M., DENG R. Nanoscale zero-valent iron coated with rhamnolipid as an effective stabilizer for immobilization of $\mathrm{Cd}$ and $\mathrm{Pb}$ in river sediments. J Hazard Mater. 341, 381, 2018.

24. HAN J., XU Y., LIANG X., XU Y. Sorption Stability and Mechanism Exploration of Palygorskite as Immobilization Agent for Cd in Polluted Soil. Water Air Soil Poll. 225, 2014.

25. LIANG X., HAN J., XU Y., SUN Y., WANG L., TAN X. In situ field-scale remediation of $\mathrm{Cd}$ polluted paddy soil using sepiolite and palygorskite. Geoderma. 235-236, 9, 2014.

26. XU C., QI J., YANG W., CHEN Y., YANG C., HE Y., WANG J., LIN A. Immobilization of heavy metals in vegetable-growing soils using nano zero-valent iron modified attapulgite clay. Sci Total Environ. 686, 476, 2019.

27. FAJARDO C., COSTA G., NANDE M., MARTIN C., MARTIN M., SANCHEZ F.S. Heavy metals immobilization capability of two iron-based nanoparticles (nZVI and Fe3O4): Soil and freshwater bioassays to assess ecotoxicological impact. Sci Total Environ. 656, 421, 2019.

28. XU Y., LIANG X., XU Y., QIN X., HUANG Q., WANG L., SUN Y. Remediation of Heavy Metal-Polluted Agricultural Soils Using Clay Minerals: A Review. Pedosphere. 27, 193, 2017.

29. WANG H., WANG X., LI J., JING H., XIA S., LIU F., ZHAO J. Comparison of palygorskite and struvite supported palygorskite derived from phosphate recovery in wastewater for in-situ immobilization of $\mathrm{Cu}, \mathrm{Pb}$ and $\mathrm{Cd}$ in contaminated soil. J Hazard Mater. 346, 273, 2018.

30. ÁLVAREZ A.E., GARCÍA S.A. Palygorskite as a feasible amendment to stabilize heavy metal polluted soils. Environ Pollut. 125, 337, 2003.

31. FANG Z., QIU X., HUANG R., QIU X., LI M. Removal of chromium in electroplating wastewater by nanoscale zero-valent metal with synergistic effect of reduction and immobilization. Desalination. 280, 224, 2011.

32. FROST R.L., XI Y., HE H. Synthesis, characterization of palygorskite supported zero-valent iron and its application for methylene blue adsorption. J Colloid Interface Sci. 341, 153, 2010 . 
33. XUE W., HUANG D., ZENG G., WAN J., CHENG M., ZHANG C., HU C., LI J. Performance and toxicity assessment of nanoscale zero valent iron particles in the remediation of contaminated soil: A review. Chemosphere. 210, 1145, 2018.

34. FEI Y., YAN X., ZHONG L., LI F., DU Y., LI C., LV H., LI Y. On-Site Solidification/Stabilization of $\mathrm{Cd}, \mathrm{Zn}$, and $\mathrm{Pb}$ Co-Contaminated Soil Using Cement: Field Trial at Dongdagou Ditch, Northwest China. Environ Eng Sci. 35, 1329, 2018.

35. SU H., FANG Z., TSANG P.E., ZHENG L., CHENG W., FANG J., ZHAO D. Remediation of hexavalent chromium contaminated soil by biochar-supported zero-valent iron nanoparticles. J Hazard Mater. 318, 533, 2016.

36. WEN J., ZENG G. Chemical and biological assessment of Cd-polluted sediment for land use: The effect of stabilization using chitosan-coated zeolite. J Environ Manage. 212, 46, 2018.

37. LI Z.T., WANG L., WU J.Z., XU Y., WANG F., TANG X.J., XU J.M., OK Y.S., MENG J., LIU X.M. Zeolite- supported nanoscale zero-valent iron for immobilization of cadmium, lead, and arsenic in farmland soil: Encapsulation mechanisms and indigenous mircobial responses. Environ Pollut. 260, 114087, 2020.

38. YIN X., XU Y., HUANG R., HUANG Q., XIE Z., CAI Y., LIANG X. Remediation mechanisms for Cd-contaminated soil using natural sepiolite at the field scale. Environ Sci Process Impacts. 19, 1563, 2017.

39. ZHAI X., LI Z., HUANG B., LUO N., HUANG M., ZHANG Q., ZENG G. Remediation of multiple heavy metal-contaminated soil through the combination of soil washing and in situ immobilization. Sci Total Environ. 635, 92, 2018.

40. PEI G., ZHU Y., WEN J., PEI Y., LI H. Vinegar residue supported nanoscale zero-valent iron: Remediation of hexavalent chromium in soil. Environ Pollut. 256, 113407, 2020. 
